\title{
Exchange Relationships and the Efficiency Interests of the Law
}

\author{
Gregory T. Gundlach
}

\begin{abstract}
Understanding marketing's trend toward long-term exchange relationships and the practice of relationship marketing is important for both marketing and public policy. The author examines the implications this form of exchange can pose for the interests of exchange participants and society. Focusing on the legal foundations of exchange as found in the law of property and contract, the principle values that constitute this infrastructure of law provide the basis of the author's inquiry. These values are considered to stand for and reflect basic societal interests and therefore furnish an important basis from which to assess the implications of this increasingly prevalent exchange form. Results of the analysis suggest that exchange relationships can enhance the internal efficiency of participants' interaction in exchange. However, the nature of long-term exchange also can challenge aspects of external efficiency or the allocation of resources to their best possible use in society. Employing the economic criteria of social wealth, the author finds that the benefits of enhanced internal efficiency outweigh concerns posed by these exchanges for external efficiency. Implications for public policy and marketing practice and research are discussed.
\end{abstract}

$\mathbf{E}$ xchange has long been described as the core theoretical foundation underlying marketing (cf. Alderson 1957; Bagozzi 1979; Houston and Gassenheimer 1987; Hunt 1983; Kotler 1972). The discipline itself has been characterized as the "behavioral science that seeks to explain exchange relationships" and transactions (Hunt 1983, p. 13). Recently, the marketing literature has begun to address exchange as involving a range of complexity and duration. Anchoring exchange along a continuum extending from discrete transactions to relational associations, scholars studying different aspects of marketing have emphasized the varying nature of exchange (cf. Dwyer, Schurr, and Oh 1987; Webster 1992). In this respect, considerable attention has been focused on exchanges that reflect organizational forms believed to constitute the relational archetype. These exchanges involve participants engaging in complex, longterm collaborative relationships to achieve their individual goals. The rubric for these exchanges includes working partnerships (Anderson and Narus 1990), relational exchanges (Goetz and Scott 1981; Goldberg 1979; Macneil 1980), domesticated markets (Arndt 1979), co-marketing alliances (Bucklin and Sengupta 1993), symbiotic marketing (Varadarajan and Rajaratnam 1986), and networks (Ford 1980; Webster 1992), to name a few. Each reflects the idea that an exchange relationship differs markedly from a discrete transaction.

Evidence of the trend toward exchange relationships is most visible across marketing channel relationships (cf.

GREGORY T. GUNDLACH is an associate professor, Department of Marketing, College of Business Administration, University of Notre Dame. The author extends his appreciation to Patrick E. Murphy, departmental colleagues, the reviewers, and the Editor for their helpful comments.
Weitz and Jap 1995), services marketing (cf. Berry 1983, 1995), and competitive exchange (cf. Gundlach and Mohr 1992). In greater numbers, firms are emphasizing strategies of relationship marketing, with the trend toward its practice showing no signs of abatement (cf. Cravens 1995). Indeed, scholars examining this phenomenon have counseled that the movement of exchange toward emphasis of exchange relationships requires the reexamination and expansion of marketing's role and a broadening of its attendant paradigms to more appropriately capture this shift (Kotler 1990; Parvatiyar, Sheth, and Whittington 1992; Webster 1992).

Despite the trend toward exchange as a relational phenomena and its study and practice by marketers, researchers' understanding of these relationships is still in the formidable stages, with the marketing literature deficient in some important ways. In particular, questions remain as to the implications of exchange relationships both for participants and in aggregate for society. For individual participants, exchange relationships can affect parties in various ways. On the one hand, given their collaborative nature, these exchanges can result in lower costs, improved quality, enhanced performance, and greater levels of customer satisfaction (Trevelen 1987; Wilson, Dant, and Han 1990). On the other hand, because they often involve the investment of substantial resources that may be difficult to redeploy, these exchanges sometimes can result in increased costs and force participants to forgo alternate exchange opportunities. Satisfactorily servicing customers also can be more difficult because of the demands these customers may put on their partners. In this respect, Kalwani and Narayandas (1995, p. 3) observe, "There is anecdotal evidence, especially in the automobile industry, that establishing long-term relationships with existing customers can lead to reduced gross margins and in some cases even recurrent losses" (cf. Day 1990; Helper 1991; Lyons, Krachenberg, and Henke 1990).

At a more aggregate level, the implications of exchange relationships for society have not been emphasized in the 
marketing literature. Questions remain regarding the impact these exchanges can pose for competitors and consumers. Although collaborative strategies enable some firms to compete more effectively, the nature of these exchanges (e.g., emphasis on loyalty, deployment of specialized resources, long-term nature) can make it more difficult for participating firms to engage other exchange partners and compete in different markets (Miles and Snow 1992). An extreme example is the case of some Japanese keiretsus and their established suppliers. While working together, suppliers are often forbidden from doing business with firms in other keiretsus (Sakai 1990).

For consumers, exchange relationships can enable a firm to better understand customer needs and offer customized offerings through emphasis on consumer loyalty. However, the nature of customer retention strategies employed to obtain the allegiance of consumers can also limit consumers' choice alternatives through constraining their ability to engage in other exchange relationships (cf. Bagozzi 1995; Peterson 1995; Sheth and Parvatiyar 1995). Understanding these consequences and their trade-offs is important for both marketing managers contemplating relational exchange and the practice of relationship marketing and public policymakers developing exchange-related policy.

Accepting the trend toward exchange relationships and acknowledging these potential trade-offs, I address the implications of relational exchange for the interests of participants and society. Employing analysis in law, I focus on the legal foundations of exchange as found in the law of property and contract and the principle values that constitute this infrastructure of law. These values are considered to stand for and reflect basic societal interests and therefore provide an important basis from which to assess the implications of exchange as a collaborative, long-term phenomena. I identify key differences in the values of property and contract law for governing collaborative exchange. The principal values driving property law are shown to favor a transactional perspective of exchange emphasizing external efficiency through advocating clearly defined rights in property and exchanges which enable these interests to reach their best possible use. In contrast, acknowledging exchange as a relational phenomenon, the principal value of contract law is found to emphasize the internal efficiency of exchange through rules that ensure participants the freedom to develop exchanges as they desire and in the absence of outside interference. Contrasting these different perspectives and the social interests they reflect, I analyze the implications of exchange relationships and assess their trade-offs in terms of social wealth. I then report the implications of this analysis for marketing and public policy.

\section{Legal Infrastructure of Exchange}

Acknowledgment of the law as an important basis for all forms of exchange has been recognized at least from the time of Adam Smith (see Smith 1776). Although voluntary exchanges provide the primary basis of exchange in our economy, these exchanges occur against a backdrop of legal principles and rules. These principles and rules formally prescribe society's interests as they relate to exchange.

As is described in Table 1, two key areas of law constituting the legal infrastructure of exchange include property law and contract law. Property law applies to exchange through assigning basic rights and responsibilities to those having an interest in an object or thing transferred (Cribbet 1986). Contract law addresses the exchange of objects already owned through providing rules, procedures, and remedies for exchanging parties (Calamari and Perillo 1987). Although other areas of law apply with considerable overlap, the extensive domains of property law (including the law of real property, personal property, intellectual property, and so on) and contract law (including the law of contract, sales, commercial, warranty, insurance, agency, partnership, corporate, and so on) are considered to furnish a

Table 1. Legal Infrastructure of Exchange ${ }^{a}$

Law Domain Principle Value(s)

Property Real, personal, and intellectual property eation of clearly defined rights to precisely characterize a person's interests in property and provide for the efficient transfer of these interests (Holderness 1985)

Alienability of property: Flow of property from one use to another to those who can make the most productive use of it (Robinson 1991)

Contract Contract, sales, commercial, warranty, insurance, agency, partnership, corporate, joint venture, and so on.
Freedom of contract: People's freedom to interact by mutually consenting to binding exchange in the absence of external interference (Brancher 1969)
Dominant classical law of contract becoming infused with neoclassical and relational principles

\footnotetext{
"Tort law also is considered part of the legal infrastructure of exchange; its purpose is to protect persons and property from the aggression of others (Epstein 1980). For this analysis, however, tort law is excluded because of the focus on exchanges that do not involve legally wrongful (i.e., tortious) conduct.
} 
substantial legal foundation for exchange (e.g., Epstein 1980; Holderness 1985; Posner 1992). As Epstein (1980, p. 255 , note 4) observes, "[T]he function of the law is essentially threefold.... The first function is to determine the original property holdings of given individuals ... such is governed by the law of property.... The second is the law of contracts, which governs cooperative efforts among individuals and exchanges of things that are already owned." Guided by fundamental social values, the infrastructure of property and contract law is intended to provide a seamless web of legal principles and rules through which exchange may be conducted and parties ensured of receiving their bargainedfor consideration.

\section{Property Law}

The law of property addresses interests of persons relative to exchangeable objects and the movement of these objects to others. This includes the way in which these interests are assigned, enforced, and transferred (Posner 1992). For exchange, the context of these interests encompass the rights of owners in all forms of property (e.g., real, personal, intellectual) relative to others, as well as rights regarding the transfer of interests in such property as possessed (Reich 1964). Together, the many forms of property provide an important foundation for exchange.

\section{Clarity of Interests in Property}

The first value of property law is the delineation of clearly defined rights to precisely characterize individuals' interests in property and provide for the efficient transfer of these interests (Holderness 1985; see Table 1). Substantively, this means laws that endow an owner of property with a welldefined bundle of rights, including the right to exclude others and do as he or she wishes with the property. Although some limitations exist for the protection of third parties and social policy, clearly defined rights in the control and transfer of property provides the starting point and default value of property law (Frankel 1993).

For exchange, laws that endow owners with clearly defined interests in property avoid the problem of conflicting ownership and enhance the value and transferability of property. In particular, well-defined property rights clarify expectations and assure reliance interests in exchange, thereby minimizing the number of potential claimants to property. Unexpected and conflicting claims increase the risks to buyers and elevate the difficulty of accurately assessing value in property. Clearly defined property rights also enable parties to efficiently transfer their interests in property to others as they see fit and without interference. Clear rights encourage investment and exchange through reducing information and transaction costs, because parties may easily assimilate ownership information, evaluate terms of ownership, and confidently engage in the transfer of their interests (Baird and Jackson 1984).

${ }^{1}$ Epstein (1980) goes on to also include tort law, suggesting its function is to protect persons and property from the aggression of others. For purposes of the current analysis, however, tort law is excluded because of the focus on exchanges that do not involve legally wrongful (i.e., tortious) conduct.
Examples of the law's support of clearly defined rights in property is detectable across a variety of venues in property law (Gensler 1985). For example, rules pertaining to adverse possession for resolving disputes in real property (i.e., real estate) exchanges provide for and facilitate the transfer of ownership from passive claimants to active users (Holderness 1985). The nature of property interests and recording rules applicable to both real and personal property exchanges provides another illustration. Categories of ownership in real property (e.g., fee simple, joint title) clearly define ownership interests. Compulsory rules for the systematic recording of these interests (i.e., real property recording laws) further act to clarify these interests through reducing the burden and costs of obtaining information concerning such property.

Within the intellectual property domain, a generally accepted policy of property law applicable to patents and copyrights (i.e., intellectual property law) is to provide predictability and security to the property rights of inventors. In this respect, the law attempts to clarify the inventors' interests and endow them with the specific rights of control (Gensler 1985). Laws that support this outcome include the general right to exclude others from an inventive idea (i.e., patent infringement) and do as one pleases with a patent (i.e., right to refuse to license a patent). As was stated by the Supreme Court, "[a] patent owner is not in the position of a quasitrustee for the public.... He has no obligation either to use it or to grant its use to others (Hartford-Empire Company v. United States 1945, p. 324). Only in exceptional cases have the courts denied patent owners the right to enjoin continuing infringement. Moreover, though Congress has considered bills that would authorize compulsory licensing of patents, such legislation has never found significant support (Armstrong 1988).

\section{Alienability of Property}

A second value of property law involves the importance given to the flow of property from one use to another, eventually, to those who can make the most productive use of it (Robinson 1991; also see Table 1). To this end, the law of property, with some exceptions, places a high degree of importance on the free access and exchange of interests in property (Epstein 1980). Indeed, an owner's right to do with property as he or she wishes is subject to regulation when the owner's activities are contrary to the notion of alienability (Sterk 1993). Although some exceptions apply (e.g., interests in "human capital"-the law's reluctance to enforce employee covenants not to compete, bankruptcy's "fresh start" policy relating to creditor claims, etc.), the alienability of interests in property is a generally accepted principle of American property law (Rose-Ackerman 1985).

The law's preference for alienability rests on several foundations. Facilitating the efficient transfer of rights in property ensures that such interests will flow to persons whose market behavior suggests that they value them the most (Posner 1992). In this respect, alienability of interests in property serves as the foundation for a market system that minimizes both overproduction of goods and services that economic actors do not want and underproduction of goods in great demand. Moreover, alienability promotes personal autonomy by increasing people's choices concerning how to live their lives (Sterk 1993). 
Elaborate rules precluding a failure of real property rights' vesting to sequential property holders in exchange and rules precluding the prohibition of alienation (e.g., Rule in Shelley's Case, Doctrine of Worthier Title, Rule Against Perpetuities) are examples of the law's support of this alienation interest (Holderness 1985). Each ensures that interests in real property remain transferable, even at times against the wishes of the owner.

Similar rules apply to other forms of property. For example, the law prohibits agreed-to limitations on the transfer of personal property interests in corporations (Carney 1993). The law's constraint of the power of owners to carve up future and present property rights for real estate exchanges through prescribing the forms these exchanges must take further illustrates this interest. The Rule in Spencer's Case, for example, ensures that subsequent landowners are automatically assigned rights appurtenant to real property while avoiding the requirement that succeeding owners negotiate with the original landowner.

Compulsory registration of land titles is another propertybased policy doctrine that facilitates the efficient transfer of property (Gensler 1985). Registration of title enables prospective purchasers to easily access information concerning property. For exchange, laws that facilitate clear title and the movement of property enhance the efficiency of exchange through lowering transaction costs to interested parties.

\section{Property Law and the Nature of Exchange}

Those studying property law and its evolution in modern society describe its close lineage with the historical nature of exchange activity (Anderson and Hill 1975; Cribbet 1978). Prior to market capitalism, property rights were granted to persons by the sovereign as part of the network of reciprocal privileges and obligations that bound medieval society into an organic whole (Pollock and Maitland 1898). As participation in markets replaced subsistence and barter as the means by which people supplied their needs, the law endowed valuables with the characteristics of commodities so that people might buy and sell them. The growth of market society and the increasing attribution of market value to tangibles and intangibles has continued into modern times. Labor, for example, became a commodity over the course of several centuries. The reification of inventive ideas came later. Today, this process continues as rights are accorded to interests in personal, intellectual, and "newer" forms of property (Reich 1964; also see Table 1).

Paralleling expansion of the concept of property to encompass differing forms of property has been the gradual redefinition of the bundle of rights inuring to property holders. In particular, over the last several decades, it is commonly regarded that there has been an increase in the social responsibilities required of property holders and as a result, a corresponding decrease in their individual right to exclude others (Reich 1964). Contrasting such a conception of property with prior property ideology, one commentator has observed,

A concept of property with maximum private rights and minimal social responsibilities suited the mood and the reality of pioneers in a vast, underdeveloped continent.... But the reality ... of life in Twentieth Century America has changed and so has our concept of property ... that the ownership of land involves societal responsibilities and duties as well as individual rights (Cribbet 1986, pp. 39-40).

Although various theories exist regarding the evolution of property law to its current status, the majority of scholars studying the law contend that it remains wedded to its earlier values (e.g., Frankel 1993; Rose 1988). ${ }^{2}$ These theorists point out that society, and therefore property law, continues to place a high degree of emphasis on laws that provide for clearly defined rights in property and furnish an owner the freedom and right to use his or her property as desired and free of the intrusion of others (Holderness 1985). In addition, considerable importance continues to be placed on laws and policy that provide for access and movement of property to those that value it the most. As Cribbet (1986, p. 42) notes, "Our changing property concepts have not abandoned the individuals' 'rights to possess, use, and dispose of property,' but they have included a greater infusion of societal rights." These scholars further contend that the underlying values of property law are necessary for efficient exchange to occur and the institution of property to remain a viable body of law (e.g., Baird and Jackson 1984; Holderness 1985; Rose 1988).

\section{Contract Law}

Another key area of law composing the legal infrastructure of exchange involves contract law. The law of contract is concerned with facilitating the voluntary movement of property rights among exchanging parties (Posner 1992). It addresses promises made between these parties for the breach of which the law gives a remedy, or the performance of which the law recognizes a duty (Restatement of Contracts 1981). As a body of legal thought, contract law, in all its forms, administers across the range of exchange contexts, from transactions (i.e., common law of contract) to relation-

\footnotetext{
${ }^{2}$ At least one scholar has suggested that the expansion of property law to incorporate a greater "social function" has as its basis the modernization of exchange to embrace relational elements (Armstrong 1988). Armstrong (1988) contends that society's retreat from market-based transactions and the domestication of exchange has resulted in the diminution of basic individual rights in property in favor of more society-oriented responsibilities He observes that the evolution of exchange to involve collaborative interaction has led to the redefinement of those processes that originally yielded the basis for rights in property, namely, the creation of value through the ability to exclude others from a person's own property and the ability to voluntarily transfer such property. Characterizing this process, Armstrong (p. 82) observes,

Bargained for exchange [has] become the exception rather than the rule in standardized transactions such as consumer purchases, the hire of labor, and rental housing. The various goods available for purchase are not differentiated in any meaningful sense and the immediate seller often has no expertise in his wares. The absence of any differentiation among sellers and products, and the growing political power of consumers, leads to government legislation regulating sales under norms more closely akin to administration than contract.

According to Armstrong, the administration of exchange has resulted in a "retreat from the market" in favor of greater governmental intervention to effectuate society's interests. To accommodate this withdrawal, he observes that the law of property has moved from a composition of wellspecified rights that facilitate valuation and exchange as a market-based phenomenon to a regime of law through which the collaborative aspects of exchange are accommodated and societies' other interests realized.
} 
ships (e.g., sales, commercial, warranty, insurance law) to organizations (e.g., agency, partnership, corporate law). Together, the many forms of contract law provide an important foundation for exchange.

\section{Freedom of Contract}

The guiding value of contract law is the support of a person's freedom to interact by mutually consenting to binding exchange in the absence of outside interference (Brancher 1969; also see Table 1). The common phrase, freedom of contract, originates from this principle. Freedom of contract posits that a contract is the creation of the exclusive wills of the exchanging parties, its terms depend solely on their subjective wills, and the desires that motivate a person's will are irreducible and beyond the grasp of any other person (Rosenfeld 1985).

The basis of providing parties the freedom to conduct their relations as they see fit extends from the law's desire to afford partners the free exercise of their wills in developing exchange arrangements. In this respect, the law itself cannot be expected to anticipate the content of the infinite number of atypical transactions into which exchanging partners might contemplate engaging. To accommodate this interest, contract law furnishes parties the freedom and protection to establish their own relations (Kessler 1943). The assumption is that parties are in the best position to arrange their affairs to maximize their exchange goals.

Against the backdrop of freedom of contract, exchanging parties are presumed to possess relatively equal bargaining power, be independent, and be capable of fending for themselves in an exchange (Calamari and Perillo 1987). Only under limited circumstances, in which the assumptions underlying freedom of contract notions are violated, does the law intervene to interpret and enforce a bargain.

Examples of contract law's central value can be observed across the entire spectrum of the law of contract. With few exceptions, the general rule is that parties are free to make their own contract. This theme is detectable within the Uniform Commercial Code (UCC) (1978), the common law (Kessler 1943), and the Restatement of Contracts (1981) (see also Brancher 1969). From interpreting parties' intentions regarding the development of an exchange relationship (e.g., doctrines regarding contractual assent, offer, acceptance) to interpretations regarding the terms of their relationship (e.g., rules regarding contract construction and interpretation-parole evidence rules), freedom of contract notions pervade contract law (Calamari and Perillo 1987). In each case, the intentions of the parties are controlling, with courts being careful not to make a "new" contract but only to reasonably interpret the parties' intentions and thus observe the parties' freedom to assent, construct, and administer their own exchange arrangements. The law even respects the exclusiveness of an exchange arrangement through various doctrines associated with privity (Kessler 1943).

\section{Contract Law and the Nature of Exchange}

Scholars studying the evolution of the law of contract have also observed its adaptation to the nature of exchange activities (see Table 1). In this respect, three legal contract traditions thought to have paralleled and evolved alongside the nature of exchange as it has developed in society are identifiable. $^{3}$

The dominant and longest standing of these three traditions is classical contract law, or the doctrine and principles developed historically in the common law. Under this model of contract, exchange is associated most closely with that of a transaction. Its effectuation is achieved through formalistic rules and principles that delimit exchange to that of a zero-sum, single issue "market" transfer. Describing this model, one scholar has observed that

the identity of the parties to a transaction is treated as irrelevant.... Second, the nature of the agreement is carefully delimited, and the more formal features govern when formal (for example, written) and informal (for example, oral) terms are contested. Third, remedies are narrowly prescribed such that ... the consequences are relatively predictable from the beginning and are not open ended (Williamson 1979, pp. 236-37).

Because of the many exchanges that have evolved to encompass more than discrete transfers to which the classical contracting scheme most usefully applies, an emergent form of contract law has developed and infused existing doctrine. Neoclassical contract law represents a more modern perspective of exchange intended to address problems inherent in exchange relationships. These include the inability of participants to anticipate and incorporate in their agreements future contingencies and make necessary adaptations to changed circumstances as contemplated under freedom of contract notions. ${ }^{4}$ The associated potential of one party taking advantage of another, given the less than discrete nature of these relationships, has also prompted adaptations in the law. ${ }^{5}$

While providing governance applicable to some exchange relationships (e.g., repeated transactions, long-term relationships), the increasing prevalence of exchange forms that come close to or mirror internal organization (e.g., strategic alliances, joint ventures) has prompted development of still a third tradition of contract law beyond the neoclassical paradigm. Relational contracting represents a "spin-off ... from the classical, and ... neoclassical contract law system[s]" (Macneil 1978, p. 885). This model of contract law addresses those exchanges in which parties deal with one

\footnotetext{
${ }^{3}$ Excerpts from this section rely extensively on Gundlach's (1994) work.

${ }^{4}$ As to the inability of anticipating future contingencies, neoclassical doctrine permits, in contrast to classical interpretations, parties to modify their agreements during the course of their relationship (Narasimhan 1987). Contemporary modification doctrine emphasizes the beneficial effects of adjustments when circumstances not contemplated exist (Graham and Peirce 1989). Similarly, under the UCC (1978), which applies to the sale of goods, a variety of "gap filler" provisions enable parties to agree to complete terms of their agreement (e.g., price, place of delivery, time of performance) at a later date (Section 2-209[1]). The code also permits these terms to be completed through reference to prior dealings between parties or customary practices in the trade (Sections 2-204/31 and 2-305 through 2311 ).

${ }^{5}$ Examples include the UCC's (1978. Section 2-103) requirement that parties adhere to the standard of "good faith" and "reasonable commercial standards of fair dealing in the trade." These standards are treated liberally by the courts, which sometimes even impose terms and conditions on exchanging parties not originally contemplated by them or circumvent terms contemplated. In addition, doctrines such as promissory estoppel and unjust enrichment have developed to protect parties possessing a reliance interest (Metzger and Phillips 1983) or wherein one party's partial performance confers a benefit on another to the detriment of the performing party (Farnsworth 1987).
} 
another repeatedly and under such complex circumstances that formal governance under the classical and neoclassical versions of contract must be supplanted through informal mechanisms (Macneil 1981).

At its core, relational contracting holds that the primary basis of governance for long-term complex exchange associations resides in the elaborate network of relationships underlying the exchange. This network is viewed as comprising both legal and extralegal devices of governance. Extralegal devices include less formal governance mechanisms, such as social norms, ethics, and the influence of reputation. In contracting terms, the law is more relational to the extent that it relies on these extralegal governance devices in its rules and requirements (Goetz and Scott 1981). ${ }^{6}$

Together, examination of the nature and forms of contract law suggests the law's attempt to accommodate the evolution of exchange from transactions to relationships through its freedom of contract value. In this respect, the primary approach taken in the law has been to rely increasingly on extralegal devices for governing exchange relationships. The infusion of such regulatory mechanisms as good faith, reference to prior dealings between parties, customary practices in the trade, and the imposition of duties of loyalty, disclosure, and so on permits the law to be flexible to changed circumstances in ongoing exchanges. Other adaptations in the law protect parties interests so that exchange can be conducted overtime (e.g., promissory estoppel, unjust enrichment). Notwithstanding these considerable adaptations, some scholars contend that the applied law of contract requires still further adaptation to sufficiently address modern exchange relationships and effectuate freedom of contract values (e.g., Gilmore 1974; Gundlach 1994; Macneil 1974, 1978; Scott 1990). These commentators support even greater changes in the law as it is applied to address the nature of exchange relationships.

\section{Analysis of Exchange Relationships}

Both property law and contract law have addressed the evolving nature of exchange activities over time. However, each provides a unique perspective championing different values. Property law posits a relationship between a person possessing property rights and all other people. In contrast, contract law contemplates the relationship of parties bound by promises to one another. Property law focuses on the market, whereas contract law focuses on the actors. Property law emphasizes clear rules regarding rights of ownership and control (i.e., clarity of rights), as well as free access and unobstructed flow of these rights to those that value them the most (i.e., alienability). Contract law emphasizes accommodating parties' promissory intentions and their freedom to engage in exchange as they wish (i.e., freedom of contract).

\footnotetext{
${ }^{6} \mathrm{As}$ a body of legal doctrine, relational contracting is best represented in the contract law of business organizations (i.e., corporate, joint venture, and principal-agent law). The underlying structure of these areas is founded on relational principles (e.g., reliance on fiduciary duties of loyalty, disclosure, responsibility). An often-cited case in joint venture law states, "Joint adventurers, like copartners, owe to one another ... the duty of the finest loyalty" (Meinhard v. Salmon 1928, pp. 463-64). In corporation law, fiduciary duties have always been a mainstay of the relation of corporate members.
}

For discrete or market-based exchanges, the guiding values of property and contract law furnish support and work in concert, providing for a reduction in the cost of negotiating and transacting exchanges. In these exchanges, parties are narrowly concerned with obtaining the benefit of their armslength bargain in the least costly fashion. Focus is given to the efficient exchange of goods and/or services between participants and the relinquishment and acquisition of an unencumbered interest in these goods and/or services. Property law, through its emphasis of clear rules regarding ownership and the efficient transfer of these rights, facilitates such exchanges. Similarly, contract law's accommodation of parties' intentions through its freedom-of-contract value ensures the desired transactional nature of such exchanges.

When exchange is of an extended duration involving relational interaction, however, the law's support is not unequivocal nor are the values of property and contract law completely compatible. Although contract law has evolved in an attempt to facilitate these exchanges through its emphasis of contractual freedom, property law's continued emphasis of clearly delineated ownership rights and the creation and maintenance of efficient market transfers of these rights stands in contrast to the conception of exchange as involving a long-term relational association. I here show that the unique nature of these exchanges directly challenges the principal values espoused in property law while being consistent with the key value of contract law.

\section{Characteristics of Exchange Relationships}

An effective basis for analyzing the nature of exchange relationships relative to the interests of property and contract law is to focus on the distinctive nature of these exchanges. Recently, researchers in marketing and its related disciplines have attempted to enhance our understanding of the nature of exchange relationships. They view this form of exchange as involving an interactive process, and a variety of different characteristics have been emphasized in the literature. For example, this research has shown that these exchanges require, in contrast to transactions, considerable planning, tailoring, and customization among participants to meet each parties' long-term goals (Macneil 1978). In addition, considerable information sharing among the exchanging parties also is required and involved (Mohr, Fisher, and Nevin 1994). However, information disclosure to third parties is often a concern (Sinha and Cusumano 1991). Once parties have become involved and the exchange relationship is ongoing, further efforts and inputs are required as parties contemplate changed circumstances and attempt to ensure the future of their association (Macneil 1980). Each of these characteristics are summarized in Table 2 and examined subsequently as a basis for illustrating the nature of exchange relationships and the key values of property law and contract law.

\section{Planning, Tailoring, and Customization}

A prominent feature of exchange relationships is their extensive planning, tailoring, and customization (Macneil 1978). In contrast, discrete exchanges (i.e., transactions) involve less planning and specialization, relying more on ad hoc interaction and arms-length bargaining. Planning and specialization provide exchanging parties with the ability to 
Table 2. Legal Analysis of Exchange Relationships

Nature of

Exchange Relationships

Planning, tailoring, and customization

Information sharing and third-party disclosure

Responding to changed circumstances

Ensuring the future of the association
Interests of the Law

Contract Law Property Law

Freedom of contract. Parties are allowed to develop the terms of their relationship as they see fit.

Exchange as a standardized process. Parties are generally restricted in how they structure their exchange associations.

Emphasis of exchange participants. Imposes formalities and requirements of disclosure among participants. Parties are not required to disclose their relationship to third parties.

Common law allowed few modifications to respond to changing circumstances. Modern expression of the law permits modifications.

Interpersonal relations fostered. Parties' intentions are controlling.
Emphasis of exchanging parties' relationship to third parties. There are significant disclosure requirements to third parties.

Few modifications for changed circumstances are allowed, to establish clear rights of ownership and transfer.

Durable exchange relationships are disfavored. Free transfer of interests are controlling. develop exchanges that specifically meet their needs. ${ }^{7}$

Property law and contract law differ markedly in their permittance of tailoring and customization of exchanges. Contract law has as its basis the policy of allowing parties the freedom to contract. Parties are allowed with some exception (e.g., illegal exchanges, prohibitions against penalty damages) to develop the terms of their relationship as they see fit (Farnsworth 1990). Exchanges may be drafted that permit unique substantive rights and remedies inuring to each party. Similarly, parties are allowed to express these terms in such a fashion as to be interpreted at a later date (UCC 1978). More recent adaptations in contract law further recognize parties' freedom to specialize their relationships. Allowing parties to tailor and customize their exchanges enables parties to develop exchanges that best reflect the interests of the parties involved.

In contrast, in an effort to ensure the alienability of interests in property, the law of property imposes more restrictions on how parties can structure their association. Property law generally requires a greater standardization of terms and rights (Frankel 1993). Recall, for real property exchanges, standardized forms of transfer and standardized classes of property rights in real property exist (Becker 1980). Relat-

\footnotetext{
${ }^{7}$ Research in marketing illustrates this point. In the context of just-intime relationships, Frazier, Spekman, and O'Neal (1988), for example, speak of the supplier becoming an extension of the original equipment manufacturer producer and vice-versa, with the need for extensive planning and specialization. O'Neal (1989) observes empirical support for greater levels of participation between partners in these relationships. In describing a normative framework for the development of purchasing partnerships, Ellram (1991) details the extensive steps required to form these relationships. In addition, several authors have observed the role of resource specialization as both a contributing factor and an outcome of complex exchange relationships. Heide and John (1990), for example, find that close working relationships emerge in response to the need to protect relationship-specific assets. Others suggest these same customized assets can signal a willingness to engage in these relationships (Anderson and Narus 1990; Anderson and Weitz 1989, 1992; Gundlach, Achrol, and Mentzer 1995; Salmond and Spekman 1992).
}

edly, official weights, quantity standards, and labeling requirements are mandated by law for some personal property exchanges (e.g., U.S. grain standards, federal labeling requirements for food). Although some areas of property law are notable in their allowance of customized and tailored exchanges (e.g., leases, whole loans), property law remains, for the most part, committed to exchange as a standardized process (Dukeminier and Krier 1988). Standardization fosters market efficiencies through reducing information and transaction costs and lessening confusion among market participants.

\section{Information Sharing and Third Party Disclosure}

Exchange relationships, in contrast to transactions, involve the extensive transfer of information between exchanging parties. The sharing of information is necessary inside complex relations and aids in the establishment and furtherance of these associations (Mohr, Fisher, and Nevin 1994). ${ }^{8}$ At the same time, public disclosure of information outside the relationship can entail individual (e.g., proprietary information) and competitive risks (Sinha and Cusumano 1991). ${ }^{9}$

\footnotetext{
${ }^{8}$ The need for more frequent communication and information sharing in collaborative exchanges has been observed by several researchers. $O$ 'Neal (1989) reports higher levels of intensity and interaction between members of just-in-time relationships as well as a greater willingness to communicate (cf. Frazier, Spekman, and O'Neal 1988). The close linkage between communication and cooperation in working relationships also has been observed by Anderson and Narus (1990) and others (cf. Heide and John 1992; Noordewier, John, and Nevin 1990).

${ }^{9}$ Regarding the disclosure of information external to the relation, anecdotal evidence suggests this prospect to be of concern in these exchanges. Sakai (1990), for example, reports that in many Japanese keiretsus, members adhere to strict rules regarding disclosure of information. Kalwani and Narayandas (1995) also report the often-held expectation in joint product development relationships and other relationships that partners not use the technology developed in the relationship in dealing with others. Finally. Sinha and Cusumano (1991) report that in competitor research joint ventures, firms often prefer smaller partners as a basis for limiting the sharing of research results.
} 
Both property and contract law impose requirements regarding information sharing and disclosure; however, each differs in its orientation and the extent of privacy accorded participants. Contract law emphasizes the exchanging parties, imposing on these parties' formalities and requirements of disclosure to one another (Farnsworth 1990). For example, various formalities across the process of exchange distinguish and ensure that participants are knowledgeable about the status of their relationship (e.g., formalities of offer, acceptance, consideration, revocation). Adhering to freedom-of-contract values, each party is responsible for gathering information in the exchange; however, participants are required to provide accurate and truthful information to one another. As to disclosing information to third parties, contract law does not require parties to publicize, for the most part, the existence of their relationship, its terms, or its duration. Indeed, parties can keep their relationship confidential and can impose through the law such confidentiality and duties on one another. Third parties (e.g., other market participants) must gather information at their own expense.

Property law, on the other hand, has as its primary orientation, the exchanging parties relationship to third parties versus the parties themselves. Under property law, depending on the type of property, sellers have significant disclosure requirements (Frankel 1993). These requirements can extend not only to disclosure of the occurrence of an exchange, but also to the terms and ownership interests of the participants involved (Holderness 1985). Mandatory registration of land titles provides one example. Requiring owners of land to register clarifies interests in property and enables prospective buyers to easily contact sellers. The sale of consumer commodities and food provides another example requiring significant public disclosure under the labeling laws. Similarly, the sale of securities and bulk sale of business involve significant publication requirements (to creditors and other lien holders) as do some forms of real property (to other potential titleholders). The disclosure requirements of property law facilitate the efficient transfer of interests in property through reducing information costs to potential buyers. Publication requirements also clarify interests in property through ensuring that all prospective claimants have notice of exchanges.

\section{Responding to Changed Circumstances}

Because of the intertemporal nature of relational exchanges, changed circumstances requiring adjustments in these associations often occur. The inability to contemplate such circumstances and adjustments at the inception of an exchange relationship requires that parties be able to modify their arrangements as needed. ${ }^{10}$

\footnotetext{
${ }^{10}$ The majority of process frameworks developed in marketing and related fields, which characterize the stages of exchange relationship development, describe the requirement that parties interactively consider the necessity of modifying arrangements as they evolve over time (cf. Dwyer, Schurr, and Oh 1987; Ellram 1991; Frazier, Spekman, and O'Neal 1988; Gundlach 1994). In other work, Heide and John (1990) speak of verification efforts as a basis for assessing the need to respond to changing circumstances in exchange relationships. Finally, the mutual basis and cooperative efforts toward addressing changed circumstances has been observed as a key quality of long-term exchange associations (Macneil 1980).
}

Both property law and contract law differ in the extent to which they allow parties to modify their exchange arrangements over time. Whereas the common law of contract tends to allow few modifications with relatively few exceptions, the modern interpretation of contract law's freedom-of-contract value permits parties to alter, to some degree, their agreements to accommodate changed circumstances (Farnsworth 1990). The furthest expression of this is found in those areas of contract law that allow parties to leave important terms of their relationship "open" to be completed or interpreted at a later time period (UCC 1978, Sections 2204[3] and 2-305 through 2-311). Indeed, the UCC explicitly allows modification of existing relationships to address changed circumstances. According to the UCC, "an agreement modifying a contract within this Article needs no consideration (i.e., an additional benefit or burden beyond the original consideration inducing a party to contract) to be binding" (Section 2-209[1]). These freedoms enable exchanging parties to modify their agreements to changed circumstances easily.

In contrast, property law permits few modifications to relationships because of its desire to establish clear rights of ownership and transfer. An example involves covenants running with the land (Holderness 1985). Affecting most residential and commercial real estate exchanges, these agreements among neighboring landowners restrict land use. They can take various forms, including height restrictions on buildings, agreements not to engage in certain business, prohibitions on fences, and so on. Under property law, a generally recognized rule is that subsequent landowners (including purchasers) are required to honor covenants burdening their property even though they were not parties to the original exchange agreement and circumstances may have changed. When an initial landowner sells property, the obligations under these covenants automatically pass to the new owners regardless of circumstances or what agreement has been reached. Such a policy clarifies parties' interests and avoids renegotiations involving subsequent landowners, thus providing for the efficient transfer of property. Such a rule, however, also inhibits the parties' abilities to respond to changed circumstances.

\section{Ensuring the Future of the Association}

A distinguishing feature of exchange relationships involves their durable nature. Successful relationships are those that survive conditions of stress and other strains to their existence. " A long-standing policy of contract law is that interpersonal relations should be fostered. Rights under a contract, for example, are difficult to transfer without the consent of both parties (Corbin 1963). Moreover, when terms to a contract prohibit its assignment, the general rule is that such terms will be upheld (Farnsworth 1990). Other areas of

\footnotetext{
"The durableness and long-term orientation of collaborative exchanges has been observed by several researchers in marketing. Noordewier, John, and Nevin (1990) propose, for example, that expectations of contimuity in a relationship, which captures the chance of future interaction, is a defining characteristic of relational exchange. The high likelihood of future interactions in these exchanges has been observed by Ganesan (1994), who studies the antecedents of long-term orientation in exchange. Furthermore, Heide and John (1990) report that continuity expectations is an antecedent to closer manufacturer-supplier relationships.
} 
contract law also support continued exchange (cf. Frankel 1993). Under partnership law, for example, the formation of a partnership establishes a highly personal relationship involving both partnership rights (i.e., contractual) and ownership interests (i.e., property interests). A partner may not assign contractual rights to a partnership (e.g., to vote, manage, and represent the partnership) but may assign ownership interests therein.

Property law disfavors durable exchange relationships through rules against parties interfering with the free transfer of rights to property. Unless imposed by a statute or the unique nature of the property right, the starting point of property law is that property rights should be freely transferable (Frankel 1993). This requirement, in some instances, can interfere with the continuing nature of relational exchange. Indeed, a general rule of property is that restrictions on the transfer of rights constitute illegal restraints on alienation (Holderness 1985).

\section{Efficiency Interests of Property and Contract Law}

Contrasting property and contract law, my analysis to this point suggests that the legal foundations of exchange differ from one another in their governance of exchange relations. Although the principal values that drive property law (i.e., clear interests in property and free alienability) define exchange as a market phenomenon and appear to contrast with the nature of exchange relationships, contract law's freedom-of-contract value as it has been developed over time suggests, at minimum, its sanction of exchange as a relational process.

Accepting that each of the key values of property and contract law stand for and reflect fundamental interests of society, a key question relates to the implications of exchange evolving toward the relational archetype for these basic interests. In particular, what consequences does this trend pose for the clarity of rights in property and the alienability of these rights as championed by property law, as well as the freedom of parties to conduct their exchange relations as they see fit as promoted through contract law? To address these questions, I characterize the fundamental values of property and contract law in terms of their respective efficiency goals. These normative goals are then employed as a basis for examining the efficiency implications of exchange as a relational phenomenon. Efficiency-based analysis is a widely employed method of legal and social analysis (Posner 1992).

Table 3. Exchange Relationships and the Efficiency Interests of the Law

\begin{tabular}{|c|c|c|c|c|c|}
\hline \multirow{2}{*}{ Property Law } & & & $\begin{array}{l}\text { 2. Alienability of } \\
\text { property: Efficiency } \\
\text { is enhanced when } \\
\text { rights in property } \\
\text { are readily } \\
\text { transferable. }\end{array}$ & $\begin{array}{l}\text { 2. Results in con- } \\
\text { straints for the } \\
\text { transferability of } \\
\text { property interests. }\end{array}$ & $\begin{array}{l}\text { 2a. Positive: Pro- } \\
\text { vides safeguards to } \\
\text { participants who } \\
\text { would not otherwise } \\
\text { transfer resources to } \\
\text { an exchange repre- } \\
\text { senting the best use } \\
\text { of the resources. }\end{array}$ \\
\hline & & & & & $\begin{array}{l}\text { 2b. Negative: Can } \\
\text { hinder the transfer } \\
\text { of resources in an } \\
\text { exchange to more } \\
\text { valuable uses in } \\
\text { other exchanges. }\end{array}$ \\
\hline Contract Law & $\begin{array}{l}\text { Internal: Partici- } \\
\text { pants involved in } \\
\text { exchange. }\end{array}$ & $\begin{array}{l}\text { Coordination of } \\
\text { activities to maxi- } \\
\text { mize input } \\
\text { resources and mini- } \\
\text { mize process costs } \\
\text { associated with } \\
\text { such resources. }\end{array}$ & $\begin{array}{l}\text { Freedom of con- } \\
\text { tract: Efficiency is } \\
\text { enhanced when par- } \\
\text { ties are given the } \\
\text { freedom to coordi- } \\
\text { nate their exchange } \\
\text { activities as they } \\
\text { desire and without } \\
\text { interference. }\end{array}$ & $\begin{array}{l}\text { Involves extensive } \\
\text { coordination } \\
\text { between partici- } \\
\text { pants. }\end{array}$ & $\begin{array}{l}\text { Positive: Can pro- } \\
\text { vide cost savings } \\
\text { and maximize } \\
\text { inputs through scale } \\
\text { economies, learn- } \\
\text { ing, and reduced } \\
\text { uncertainty. }\end{array}$ \\
\hline
\end{tabular}


In Table 3, the efficiency orientation, conceptualization, and operationalization of property and contract law's key values and the nature and implications of exchange relationships for these interests are summarized.

\section{Property Law's External Efficiency Interest}

Property law emphasizes the relationship of a property holder to all others, with its values aimed at (1) precisely characterizing individual interests in property relative to others (i.e., clarity of interests) and (2) assuring that such interests are easily accessed and freely transferable (i.e. alienability). Rules of property law are intended to ensure these interests through granting property owners specific rights and protections, as well as duties and obligations. When adhered to, these rules facilitate the efficient identification and movement of rights in property to those who value them the most. In this respect, a fundamental goal of the law of property may be said to be the external efficiency of exchange.

External efficiency as used here refers to the efficient allocation of resources to their best possible use in society (see Table 3). This form of efficiency involves the question of whether the nature of an exchange relationship permits resources, including goods and services, to reach their best possible use in society. ${ }^{12}$ In the context of property law, external efficiency is specifically concerned with the ability of actors to readily identify resources that are the object of exchange (i.e., clarity of interests) and easily access and engage exchange opportunities (i.e., alienability) so that these resources may be obtained and transferred to those that value them the most. As Epstein (1985, p. 972) points out, "If a property right cannot be transferred (because of unclear interests or constraints on alienation), resources will not be shifted from less to more valuable uses." According to property law, external efficiency is enhanced through maximizing the clarity of rights associated with property and minimizing encumbrances that may inhibit these resources from moving to their best possible use.

\section{Exchange Relationships and External Efficiency}

A variety of scholars have commented on the implications of exchange relationships for the clarity of property rights and their alienability. A general statement is that exchange relationships, in contrast to transactions, obfuscate the clarity of property rights and constrain the transferability of interests in property. Dwyer, Schurr, and Oh $(1987$, p. 13), for example, suggest that a key feature of relational exchanges, in contrast to transactions, is the "limited transferability [to alternative exchange relationships] ... of rights,

\footnotetext{
${ }^{12} \mathrm{As}$ it is employed here, external efficiency is similar to the notion of allocative efficiency as it is employed in economics (cf. Nicholson 1985): "Allocative efficiency is achieved when the existing stock of goods and productive output are allocated through the price system to those buyers who value them most, in terms of willingness to pay or willingness to forego other consumption" (Nicholson 1985, p. 620). In economics, focus is given to price and its implications for the movement of goods and services to their best possible use in society, whereas, here, the concept is defined to include nonprice-related aspects of exchange and, in particular, those emphasized through the law of property, which affect the allocation of resources in society (e.g., clarity of rights in property and their alienability).
}

obligations and satisfactions" that accompany these associations. Indeed, Macneil (1974, pp. 790-91, emphasis added) himself observes, "Just as virtually all the characteristics of transactions permit full and free transfer of all transactional rights and all but ultimate liability for transactional duties, so do many of the characteristics of relations have the opposite effect."

Obfuscation of property interests: Although transactions normally involve a sharp delineation of participants' interests and expectations, as Macneil (1980) points out, relational exchanges involve the sharing of benefits and burdens among participants. Indeed, a primary dimension by which these exchanges are defined is the relational nature of participants' interaction. Together, the complex and associative nature of these exchanges involve conditions that can obfuscate individual property interests.

Exchanges, such as strategic alliances and joint ventures, often involve joint ownership rights in property considered the product of the relation. Joint ventures themselves involve common equity interests in property of the venture. Similarly, the outputs (e.g., technology, information) of many strategic alliances and long-term relationships involve shared ownership rights. These examples highlight the implications exchange relationships potentially provide for the clarity of interests in property.

In terms of external efficiency or the allocation of resources to their best possible use in society, exchange relationships that blur ownership rights and reduce the clarity of participants' individual bundles of rights make it more difficult for those who value such property to identify and obtain it. In this respect, exchange relationships pose constraints for external efficiency. In the absence of clear rights in property, valued resources are more difficult to access and move to their best possible use.

Constraints on alienation: Participant's extensive customization, information sharing, and steps taken in relational exchanges toward ensuring the future of association among participants often involve limiting the transferability of interests out of the relationship. Exchanges nearer to the relational archetype, such as those that involve dual equity interests (e.g., joint ventures and some strategic alliances), typically create restrictions on the transfer of rights, obligations, and so on, because both parties possess an ownership interest in the property of the relation. Even parties involved in lesser forms of relational exchange (repeated transactions, long-term relationships, and so on) can find their ability to transfer ownership of their interests or exit these relations difficult. The high levels of commitment and the multiplex nature of relational exchanges make exiting these relationships especially challenging. Dedicated investments, specialization, and other barriers to exit can lock-up one party in an exchange precluding access to and service of others. As Kalwani and Narayandas (1995, p. 3) observe in the context of manufacturer-supplier long-term relationships, "Often, suppliers in long-term relationships have to make substantial investments that may have little or no value outside the relationship.... Tying up substantial resources could force these suppliers to give up opportunities to service other customers." 
That the nature of exchange relationships results in constraints on the alienation of rights in property poses dual implications for external efficiency. On the one hand, exchange conditions that limit participants from transferring interests out of a relationship provide safeguards to parties that would not otherwise commit resources to the particular use contemplated in the exchange because of risk, uncertainty, and so on. In this respect, constraints on alienation may encourage the investment of resources that otherwise might be invested in alternative, less efficient ways. ${ }^{13}$ When such investments are valued to a higher degree than alternative uses, conditions limiting their transfer can provide greater allocative efficiency as the resources are encouraged to be put to their most valued use.

On the other hand, constraints on the alienation of property also can hinder the efficient allocation of resources when invested resources in an exchange relationship become more valued in other uses. ${ }^{14}$ Gensler $(1985$, p. 78) cogently summarizes this potential: "Any restriction on the availability of ... resources constrains the productive potential of the economy ... property in all its forms and aspects must be transferable in order to allocate the resources to enterprises which can extract the greatest benefit from them." Limitations on the transferability of resources by virtue of the nature of an exchange constrains the movement of such resources to other more valued applications. Under such circumstances, the costs (both opportunity and real) of engaging alternative relationships and efficiently moving resources to their best possible use is increased.

\section{Contract Law's Internal Efficiency Interest}

In contrast to property law, the focus of contract law is on the relationship of participants in exchange, with emphasis on their contractual freedom to engage one another without intervention and in furtherance of their joint goals. Rules of contract law are intended to facilitate these outcomes by providing legal protection and assurances across the process of exchange. In this respect, a fundamental goal of contract law may be said to be that of maximizing the internal efficiency of exchange (see Table 3 ).

The concept of internal efficiency as employed here entails the coordination of exchange activities to maximize input resources and minimize process costs associated with

\footnotetext{
${ }^{13}$ In economics, transaction cost theory focuses on the nature and implications of safeguards for mitigating opportunism in transactions (Williamson 1985). Opportunism, or "self-interest seeking with guile," and bounded rationality (i.e., limited competence) on the part of exchanging parties are considered basic behavioral assumptions under this theory. Given bounded rationality, contractual solutions to problems of opportunism are considered less than complete. Exchange transactions involving uncertainty, recurring frequency, and transaction-specific resource investments are therefore considered to require an additional governance apparatus for safeguarding invested resources and maximizing exchange efficiency. Conditions found in exchange relationships can provide safeguards that result in these outcomes.

${ }^{14}$ In law and economics, considerable discussion of the conditions and implications of such circumstances wherein resources become more valued in other uses is provided in the literature on contract, which characterizes the theory of efficient breach (Craswell 1988). This theory asks, When is it more efficient for a party to breach a contract than to perform as promised? It attempts to identify contract remedies and other legal rules that give promisors an incentive to breach in exactly those cases when breach would be efficient (cf. Barton 1972; Birmingham 1970; Shavell 1980).
}

these resources. ${ }^{15}$ From the perspective of contract law, internal efficiency is maximized when parties are provided the freedom to contract. That is, efficiency is increased when parties are given the freedom to coordinate their exchange activities as they desire and without interference. Internal efficiencies are achieved through granting parties the legal protection to voluntarily engage in this process and providing assurances that facilitate it. In this respect, the law presumes that participants are in the best position to arrange their affairs in the most efficient fashion and will do so if they are given the freedom and protection of the law.

\section{Exchange Relationships and Internal Efficiency}

Considerable emphasis in marketing has been given to the benefits of exchange relationships for internal efficiency. Indeed, the primary focus of marketing's discussion of exchange relationships has emphasized these efficiencies (cf. Dwyer, Schurr, and Oh 1987; Webster 1992). In this respect, an often-cited impetus for relational exchange is to achieve the benefits of increased efficiency, in an internal sense, that these exchanges can provide. "The goal is to secure valued resources and technologies ... and ... benefit from improved quality and process performance and continuous cost reductions" (Kalwani and Narayandas 1995, p. 1).

Freedom of contract: Work in marketing and its related fields addresses the nature and circumstances of internal efficiencies obtained through allowing parties the freedom to design their exchange relationships as they desire (see generally Cravens 1995). Although not unequivocal, this research indicates that exchange relationships can enhance internal efficiency through, for example, relationship-specific scale economies and the implications of learning and greater certainty. ${ }^{16}$ In each case, contract law's freedom of

\footnotetext{
${ }^{15}$ Efficiency defined in this way parallels in some ways the concept of production and innovation efficiency as it is applied in economics. From an economic perspective, high productive efficiency is achieved through exchange activities that maximize the production and distribution of goods with the minimum consumption of resources (Scherer 1980). Innovative efficiency refers to and is achieved through the invention, development, and diffusion of new products and production processes. The coordination of exchange activities so as to result in such outcomes enhances their internal efficiency.

${ }^{16}$ In the marketing channels literature, for example, focus has been given to the domestication of exchange (Arndt 1979), its relational aspects (Dwyer, Schurr, and Oh 1987), and the development and management of institutional forms for obtaining efficiencies through closer, long-term relationships (cf. Anderson and Weitz 1992; Heide 1994; Heide and John 1988; Kalwani and Narayandas 1995; Mohr, Fisher, and Nevin 1996; Noordewier, John, and Nevin 1990). Relatedly, in industrial marketing, the study and implementation of exchange relationship strategies intended to facilitate greater communication, coordination, and planning between partners is notable (Jackson 1985). Institutional forms such as just-in-time inventory systems (Frazier, Spekman, and O'Neal 1988) and more general strategies have been examined in this context (cf. Jackson 1985; Spekman and Johnston 1986). A similar development is identifiable within the context of service exchanges. Lovelock (1983) and Crosby, Evans, and Cowles (1990), for example, explore and highlight the benefits of developing long-term relationships and their management to overcome the implications of service intangibility, perishability, and so on. In this respect, Gronroos (1990) suggests that short-term relationships or discrete encounters are more expensive to develop and maintain. The development process of long-term relationships within service encounters also has been characterized (Czepiel 1990). The effects of such relationships on satisfaction, retention, and prices in the service realm have been studied by Crosby and Stephens (1987).
} 
contract grants participants the free will and needed assurances to arrange their exchange relationship so that these efficiencies may be obtained.

In permitting parties to establish and maintain exchange relationships, an important efficiency is the scale economies that can be obtained through this form of exchange. In longterm relationships, for example, supplier firms can obtain higher sales and earn greater returns from resources invested in maintaining current relationships versus investments in attracting new customers (Kotler and Armstrong 1991). These economies come about through higher repeat sales, opportunities at cross-selling, and current customers attracting new prospects (Weitz, Castleberry, and Tanner 1992). Similarly, in many strategic alliances and joint ventures, a primary motivation is the scale economies that can be achieved through research and development $(R \& D)$, product development, and so on. These scale economies enable firms involved in these relationships to produce technology and innovations not likely to be obtained individually.

The effects of learning, brought about through allowing parties to engage in collaborative exchange over time, also can lead to efficiencies of an internal sense. In particular, collaborative exchanges can provide advantages by enabling participants to gain a better understanding of the needs of their partners (i.e., customers). In buyer-seller relationships, for example, such an understanding yields efficiencies in enabling firms to tailor products to better fit the needs of their customers and avoid the inefficiencies associated with developing products that do not (Trevelen 1987). For longterm relationships such as supplier-manufacturer exchanges, learning effects enable firms to improve the effectiveness and efficiency of purchasing and raw material inventory control (Trevelen 1987).

Finally, through coordinating the interests and obligations of exchanging parties in a relationship, efficiencies are also obtainable through the implications of lower uncertainty (e.g., enhancing the predictability of future events). In the case of long-term manufacturer-supplier relationships, lower uncertainty enables firms to plan and schedule cyclerelated tasks better. Proper planning and scheduling based on reliable and timely forecasts can provide absolute cost advantages through improved labor skills and production knowledge, less expediting, and lower work-in-process inventory levels (Hayes and Wheelwright 1984). Similarly, proper scheduling between manufacturing and just-in-time supplier delivery systems enables inventory and distribution costs to be lowered (Trevelen 1987).

The previous examples illustrate the nature of internal efficiencies that may accompany exchange relationships and extend from contract law's freedom of contract value. From a legal contract perspective, granting participants the freedom and protection of the law to organize their exchange relationships as they desire enables these efficiencies to be achieved.

\section{Efficiency Trade-Offs and Social Wealth}

My examination of the nature of exchange relationships and their implication for the differing forms of efficiency that underlie the principal values of property and contract law suggests that certain trade-offs may result. Although generally promotive of internal efficiency, this analysis suggests that exchange relationships can provide dual implications for external efficiency. I here examine the comparative trade-offs of these efficiency implications.

\section{Social Wealth}

Considerable literature in law and economics focuses on the comparative merits of the differing forms of efficiency relative to their contribution to social wealth (cf. Posner 1992; Scherer 1980). Social wealth in this context is defined as the "total value of all economically measurable assets in society" (Brodley 1987, p. 1025). The overall term, economic efficiency, is often associated with social wealth as an evaluative criterion, subject to the constraint that consumers should receive an appropriate share of such wealth (i.e., consumer welfare). Focusing on social wealth provides one benchmark for comparing the different forms of efficiency. Other approaches also might be used, depending on the social criteria of importance.

From an economic perspective, the consensus opinion among scholars is that productive and innovative efficiency contribute more to social wealth than allocative efficiency. As Brodley (1987, p. 1026) concludes, "Of the three types of efficiencies, innovation efficiency provides the greatest enhancement of social wealth, followed by production efficiency, with allocative efficiency ... ranking last."

Although operationalized differently, recall that external efficiency, from the perspective of property law, has analogies to allocative efficiency. Both concern the efficient allocation of resources through society. From an economic perspective, consideration is given to the implications of price for this goal. In terms of property law, emphasis is given to the clarity of rights in property and their transfer to those that value them the most. Similarly, productive and innovative efficiency, as they are defined in economics, relate to internal efficiency, as it is defined in contract law. Whereas economics focuses attention on the maximization of production and distribution with the minimum consumption of resources (i.e., production efficiency) and the invention, development, and diffusion of new products (i.e., innovation efficiency), contract law emphasizes parties' freedom of contract. The law itself presumes that participants are in the best position to arrange their affairs in an efficient fashion and will do so given the opportunity and protections of the law. Thus, while emphasizing different operationalizations, adopting an economic perspective provides some basis from which to assess the importance of the different forms of efficiency.

In economics, the basis of concluding that innovation and production efficiencies are more important than allocative efficiency rests on both theoretical and empirical grounds. In theory, economists argue that efficiencies relating to production are more important because such efficiencies increase social wealth over the entire range of goods and services output. In contrast, allocative efficiencies yield increases to social wealth only at the margin (not the entire range of output) (Williamson 1968). In addition, productiveand innovative-related efficiencies are argued to more directly affect the growth of future social wealth because (1) the gains from lower production costs are recurring and cumulative (i.e., efficiency-related savings can be reinvested 
to achieve further savings) (Johnson 1986) and (2) the gains from innovation efficiency, by definition, reflect gains to future social wealth (Brodley 1987). In contrast, increases in social wealth from enhancements to allocative efficiency are concerned with maximizing the consumption value of the current (versus future) stock of goods and services.

Empirically, these economic propositions are argued to be supported through reference to the growth in real output in the United States and other industrialized countries, which is attributable to internal efficiencies versus external efficiency (cf. Scherer 1980). Although appropriate caveats due to measurement issues and in particular the narrow (i.e., priceoriented) definition given to allocative efficiency apply to these studies, their thrust is to suggest that innovation and productive efficiencies have accounted for a much greater proportion of growth in real output than may be attributable to gains due to external (i.e., allocative) efficiencies.

\section{Conclusions}

Accepting (1) society's wealth as an important goal of exchange, (2) the related conceptual nature of the differing forms of efficiency conceived of in economies and property and contract law, and (3) those comparative assessments of the differing forms of efficiency conducted in economics, the internal efficiencies that accompany exchange relationships may be argued to be more important than the concerns that these exchanges pose for external efficiency. In economic efficiency terms, the positive benefits of production and innovation efficiencies in relative importance to social wealth outweigh those losses to allocative efficiency that such exchanges can result in. That is, the net efficiency contribution of collaborative exchange for social wealth can be argued to be positive.

In terms of my broader analysis in law, these findings suggest that potential concerns for exchange relationships, as reflected in the principal interests of property law (e.g., clarity of interests in property and their alienability), are outweighed by the benefits these relationships provide, as captured in the principal interest of contract law (e.g., freedom of contract). In short, through permitting parties the freedom to conduct their exchange activities as they desire and with minimal interference, participants are able to arrange their relationships to achieve outcomes that outweigh those shortfalls extending from the lack of clarity and constraints to the transferability of interests in the property that is the object of such exchanges.

Such a conclusion, however, must be accompanied by the appropriate caveats. First, comparative assessments employing social wealth or the total value of all economically measurable assets in society as the criteria of comparison may be limited in terms of its capture of society's principal interest. Other criteria of concern may yield different outcomes in assessing these efficiencies.

Second, some caution in interpreting the comparative assessments that have been conducted in economics to suggest the importance of the differing forms of efficiency is advised. As was mentioned, these comparisons have typically adopted a narrow definition of allocative efficiency, reflecting only the implications of price. Examination provided here emphasizes external efficiency as operationalized through the principal values of property law (e.g., clarity of interests in property and their alienability). Although con- ceptually similar in their concern for the allocation of resources to their best possible use in society, these operationalizations are distinct. Measures of the variation and importance of allocative efficiency based on price may not fully capture those factors emphasized through property law.

Third, beyond caveats regarding the criteria of comparison and operational distinctions, it is important to observe at a more fundamental level that alternate perspectives may emphasize other values and goals different from those focused on in this analysis of the legal infrastructure of exchange and may result in different findings than those reported here. The study of these perspectives is encouraged to understand more fully the implications of the trend toward long-term exchange relationships and the practice of relationship marketing.

\section{Implications for Marketing and Public Policy}

A variety of implications extend from my examination and analysis of (1) the shift of exchange toward complex longterm associations (e.g., exchange relationships), (2) the underlying values of property and contract law constituting the legal infrastructure of exchange, (3) the nature of exchange relationships relative to these values, (4) the implications exchange relationships pose for the efficiency interests for which these values stand, and (5) the comparative assessment of these efficiencies for social wealth.

\section{Practice of Marketing}

For marketing, assessment of the net efficiencies that can be obtained through engaging in exchange relationships suggests that the current paradigm shift to embrace relationship marketing as a valued strategy represents a positive evolution in the practice of exchange and marketing. ${ }^{17}$ In an aggregate sense, though appropriate caveats apply, analysis of these exchanges indicates a positive trade-off between the benefits of exchange relationships for internal efficiency and their potential concerns for external efficiency. Although questions regarding the clarity and some aspects of the alienability of interests in property exist for this form of exchange, these concerns appear to be outweighed by the internal efficiencies these exchanges can provide to society.

At a more tactical level, the analysis provided here suggests that prior to adopting the relational exchange format as an exchange strategy, marketers should reflect on and consider the specific implications these exchanges can yield for the different forms of efficiency. As is summarized in Table 3 , exchange relationships can yield positive contributions to internal efficiency in the form of scale economics, effects of learning, and so on. In addition, the safeguarding nature of exchange relationships can enhance external efficiency through encouraging the investment of resources that may not otherwise be invested except for such safeguards. These exchanges, however, also may create concerns for external efficiency through obfuscating the clarity of rights in prop-

\footnotetext{
${ }^{17}$ This is not to say that one exchange format may be universally desirable to the exclusion of others. Rather, the evolution of marketing to recognize and embrace formats beyond discrete transactions (e.g., relationships) represents a positive evolution of the practice of marketing and exchange.
} 
erty and limiting the transferability of such interests out of an exchange to a new better use. In each case, these potential outcomes should be assessed, prioritized, and balanced against one another prior to embarking on such a strategy. When concerns for the clarity of property interests and the transferability of interests to subsequent exchanges is important, choice of an exchange relationship as the form of exchange organization may not be optimal. Alternately, when internal efficiencies or safeguarding the transfer of resources out of an exchange are paramount, exchange relationships may provide advantages. In either case, careful selection of exchange partners, periodic reevaluations, and efforts toward balancing trade-offs among the exchange forms is suggested.

When engaging in exchange relationships, marketing practitioners also should be conscious of the current legal infrastructure of exchange as described here-in particular, that aspects of this infrastructure (i.e., property and contract law) possess different perspectives, champion different values, and sometimes establish competing requirements for this exchange form. Property law, though not equivocal, places some restrictions on the freedom of parties to engage in activities that are important for building (e.g., planning, tailoring, and customization; information sparing and disclosure) and sustaining (i.e., responding to changed circumstances; ensuring the future of the association) relational exchanges. Also, the nature of relational exchanges as supported through contract law imposes some constraints on interactions and exchange with third parties (i.e., information sharing, third-party disclosure). Prior to engaging in exchange relationships, therefore, practitioners should be sensitive to the differing orientations and values underlying property and contract law and the contingencies and implications these differences pose for the planning, creation, and administration of exchange strategies. Obtaining the counsel of professionals versed in the law is advised in this respect.

\section{Research}

In terms of broadening the understanding of exchange through research, focus on the implications of exchange relationships represents a viewpoint worthy of continued scholarly study in marketing. The evolution of exchange toward complex long-term relationships is an important trend in marketing. Study of the implications these exchanges pose for participants and society can help marketers understand this phenomenon more fully.

Although the perspective taken and findings observed here focus on the examination and comparison of the efficiency interests espoused through the legal infrastructure of exchange, other perspectives and more particular interests as they relate to this phenomenon may obtain different results and should also be examined (e.g., equity, distributive justice, choice, moral values, ethics). Of these, in-depth study of the implications of exchange relationships for choice both in the consumer and business context seems especially important and relevant to the perspective adopted here. Sheth and Parvatiyar (1995) observe choice reduction to be a "basic tenet" of relationship marketing. Although explored to some extent here (e.g., constraints on alienation of property rights), further study may wish to focus on the implications of choice reduction for exchange participants and aggregate society. Specifically, what advantages and disadvantages accrue to exchange participants and society through choice reduction, as it is brought about through relationship marketing.

Within the specific context of the perspective explored here, further study of the interests and values extending from property and contract law and their relationship to exchange also is needed. In particular, continued mapping of the nature and extent of internal and external efficiencies that these relationships can provide (or jeopardize) is required. To date, emphasis provided in marketing has been on identifying the positive enhancements to internal efficiencies in terms of value creation and cost reduction-and for internal efficiency, the safeguarding nature of exchange relationships. Similar emphasis should be given to the potential constraints these exchanges can yield for external efficiency.

Specifically, emphasis should be accorded to understanding more fully the implications of exchange relationships for other exchange opportunities. Marketing has only recently begun to acknowledge the embedded nature of exchange, namely, that exchanges do not take place in isolation, but are affected by and pose implications for other exchanges (cf. Anderson, Hakansson, and Johanson 1994).

In this respect, emergent understanding of these implications, as captured under the rubric of "network analysis," requires integration with the current relational paradigm now focused on in marketing. Network-level analysis highlights the embedded nature of exchange relationships in larger social structures and includes both descriptive and inferential methods for understanding these systems (Iacobucci 1996). Adopting a system's approach is argued to provide the advantage of better specifying the complexity of exchange relations and their broader implications.

Even within the context of a single exchange relationship, marketers' understanding of the internal efficiencies these relationships provide in terms of the value they create and the costs reductions they can provide is still lacking in many important ways. In commenting on marketing's current status in this respect, Anderson (1995, p. 348), for example, observes,

[V]alue creation and value sharing can be regarded as the raison d'etre of collaborative ... relationships. Yet, how well do practitioners or academics understand this event, or the mechanisms through which it occurs ... specifying exactly how value was added or cost reduced and assessing the magnitude of these in monetary terms appears to be both exceedingly difficult and seldom done.

Critical assessments of these efficiencies is important for fully understanding and evaluating the nature and benefits of exchange relationships. Such research should focus on the measurement of these efficiencies, the mechanisms through which they occur, and their derived implications for the management function.

\section{Public Policy}

For public policy, the increasing prevalence of exchange relationships and the demonstrated capacity of this exchange form to yield both positive and negative efficiency implications suggest their careful observation and continued assessment. In this respect, until recently, assessment of 
these efficiency implications, which was largely the province of antitrust, emphasized the positive implications extending from the minimization of costs within these arrangements (i.e., internal efficiency). ${ }^{18}$ Because of the narrow definition granted to allocative efficiency, focus on the possible shortcomings of these arrangements for external efficiency was given limited emphasis. During the 1980 s, few cases dealing with the anticompetitive implications of vertical relational exchange arrangements were brought by either the Justice Department or the Federal Trade Commission. Similarly, the climate for competitor arrangements involving $R \& D$, technology, and other arrangements was extremely receptive to relational exchange forms (cf. Gundlach and Mohr 1992).

Recently, at least for vertical exchange forms, these federal agencies have suggested that their earlier posture may have been such "as to predetermine the conclusion against enforcement action in almost every case" and may have been based on theoretical premises "expanded too far" (Davidson 1993, p. B1). In calling for a more balanced and in-depth (i.e., beyond narrow price definitions of external efficiency) inquiry, these agencies have now rescinded previously developed vertical exchange-related enforcement guidelines and are attempting to obtain a fuller understanding of the nature and competitive (i.e., efficiency) implications of exchange relationships.

A second consideration for public policy relates to the divergence of contract law's fundamental freedom-of-contract value and the structure of legal rules that currently constitute applied contract law. Scholarly research examining this legal structure continues to question its relevance and application to the relational aspects of modern exchange. Observing the law's historical development, some scholars (e.g., Gilmore 1974; Macneil 1980, 1981; Scott 1990) contend that the legal rules that constitute contract law have failed to appreciate and keep up with the realities of today's exchange relationships. Although these scholars note the advances provided through neoclassical contract law (e.g., sales, corporate law) development, they observe the continuing gap between exchange and its governance through contract law.

In this respect, the analysis conducted here may provide some solace through its recognition that the fundamental value that underlies contract law (i.e., freedom of contract) is at least harmonic with the concept of relational exchange in principle and direction. What is required, however, is continued development of the body of rules constituting contract law to properly reflect this value in the context of exchange as a relational phenomena. Only in this way may

\footnotetext{
${ }^{18}$ In antitrust terms, anticompetitive forms of relational exchange may involve complex vertical restraint arrangements (in the case of arrangements among exchange partners operating at different levels of distribution, e.g. market channel exchanges, partnerships, alliances), as well as competitor-to-competitor arrangements (e.g., co-marketing alliances, joint ventures involving competitors) intended to restrict competition. For assessing the anticompetitive implications of these arrangements, rule-of-reason analysis is employed in antitrust and involves the balancing of concerns for external efficiency (i.e., allocative efficiency) against efficiencies achieved within (i.e., internally) these exchanges (e.g., innovation and productive efficiencies) (cf. Gundlach and Mohr 1992).
}

the body of law known as contract provide a viable mechanism of governance for modern exchange.

As to public policy concerning the law of property, considerable challenges exist. On the one hand, continued emphasis of this body of law toward clearly defined, market-based exchanges stands in contrast to the nature of exchange relationships and the practice of relationship marketing. At the same time, however, the interests that underlie the principal values of property law represent important social goals. In this respect, a future challenge of public policy is the development of property-related law that retains its emphasis of clear rights in property and its alienability while being sensitive to the continued evolution of exchange toward the relational archetype. Such an achievement, however, represents no small task.

In terms of public policy relative to the infrastructure of property law and contract law, one view of the contrasting perspectives of property and contract law toward exchange is that both are essential for governing relational exchange. Contract law's emphasis of the exchanging dyad and the freedom of parties to construct their relations without interference is simply counterbalanced by property law's concern for market efficiencies through clear rights of ownership and the free alienability of these rights. Each is required, yet both serve as a check and balance to the other's underlying values.

A limitation of this view, however, is that it does not address those circumstances in practice wherein property and contract law truly conflict and thus lead to contrary outcomes. In these cases, which area of law should control? Debate centers on this issue. Advocates of market efficiency suggest property law should trump contract wherein conflicts of law occur (e.g., Frankel 1993). That is, consideration of market (i.e., external) efficiencies should outweigh freedom-of-contract notions when the law conflicts. Such a unilateral view, however, dismisses the internal efficiencies that can arise from exchange relationships as they are conceived through contract law and the comparative trade-offs of both internal and external inefficiencies and efficiencies for social wealth-both of which are examined here.

One policy resort wherein conflicts of property and contract law occur involves the actual weighing of internal and external efficiencies found to result from a particular exchange relationship against those external inefficiencies that may result. Although considerable challenge exists for sorting out such implications in a particular case, such an approach has been a mainstay of competition (i.e., antitrust) law through its rule of reason analysis. In this respect, marketing's phenomenological approach to the study of exchange relationships could provide valuable insight for understanding and assessing the nature of these efficiencies and inefficiencies.

Another perspective is that both property and contract law served exchange when exchange predominantly involved market or discrete forms. Contract law in its classical mode envisions exchange as a discrete phenomena. Similarly, property law also supports such exchanges through its discrete perspective. Over time, however, though contract law has adapted to the special needs of exchange relationships, property law has not or has done so only to a lesser degree. The implication is that in some areas of law, fundamental conflicts between property and contract do exist relative to exchange relationships. 
Following this latter perspective, the implication for public policy is less clear and even more challenging. On the one hand, such a viewpoint requires that the fundamental values that underlie property and contract law be resolved to address the requirements of exchange relationships. On the other hand, by accepting these values as reflective of broader social interests, such a view requires that the nature of exchange as a relational phenomena itself be evaluated for its overall contribution as an exchange form. Both provide unique challenges to policymakers.

\section{Conclusion}

A key development in exchange involves its evolution toward more complex, long-term relational associations. In calling for a broadened understanding of this phenomena, Webster (1992) contends that marketing scholarship would benefit from work that goes beyond the traditional disciplines of economics, statistics, mathematics, psychology, and social psychology to include analysis based in law and other areas. Addressing this call, I analyze the legal infrastructure of exchange as a basis for more fully understanding the nature and implications of exchange relationships for participants and society. Examining the fundamental values of property and contract law and the interests to society these areas of law reflect, this analysis yields a perspective of relational exchange and the practice of relationship marketing that has been given less emphasis in the marketing literature (e.g., the implications of this phenomena for participants and society). These implications, in the form of both advantages and disadvantages to social wealth, as measured through internal and external efficiencies, at minimum require participants (i.e., marketers and their partners) and others (i.e., marketing scholars and public policymakers) to examine more closely the nature and consequences of this emerging form of exchange.

\section{References}

Alderson, Wroe (1957), Marketing Behavior and Executive Action: A Fundamentalist Approach to Marketing Theory. Homewood, IL: Richard D. Irwin.

Anderson, Erin and Barton Weitz (1989), "Determinants of Continuity in Conventional Industrial Channel Dyads," Marketing Science, 8 (Fall), 310-23.

and - (1992), "The Use of Pledges to Build and Sustain Commitment in Distribution Channels," Journal of Marketing Research, 29 (February), 18-24.

Anderson, James C. (1995), "Relationships in Business Markets: Exchange Episodes, Value Creation, and Their Empirical Assessment," Journal of the Academy of Marketing Science, 23 (4), 346-50.

- Hakan Hakansson, and Jan Johanson (1994), "Dyadic Business Relationships Within A Business Network Context," Journal of Marketing, 58 (October), 1-15.

- and James A. Narus (1990), "A Model of Distributor Firm and Manufacturer Firm Working Partnerships," Journal of Marketing, 54 (January), 42-58.

Anderson, Terry L. and P. J. Hill (1975), "The Evolution of Property Rights: A Study of the American West," Journal of Law and Economics, 18 (1), 163-79.

Armstrong, George M., Jr. (1988), "From the Fetishism of Com- modities to the Regulated Markets: The Rise and Decline of Property," Northwestern University Law Review, 82 (1), 79-108.

Arndt, Johan (1979), "Toward a Concept of Domesticated Markets," Journal of Marketing, 43 (Fall), 69-75.

Bagozzi, Richard P. (1979), "Toward a Formal Theory of Marketing Exchanges," in Marketing Theory: Classic and Contemporary Readings, Jagdish N. Sheth and Dennis E. Gattett, eds. Cincinnati, OH: South-Western Publishing Company, 791-805.

_ (1995), "Reflections on Relationship Marketing in Consumer Markets," Journal of the Academy of Marketing Science, 23 (4), 272-77.

Baird, Douglas and Thomas Jackson (1984), "Information, Uncertainty, and the Transfer Property," Journal of Legal Studies, 13 (June), 299-320.

Barton, John H. (1972), "The Economic Basis of Damages for Breach of Contract," Journal of Legal Studies, 1 (June), 277-304.

Becker, Lawrence C. (1980), "The Moral Basis of Property Rights," in XXII NOMOS: Property, J. Roland Pennock and John W. Chapman, eds. New York: New York University Press, 187-220.

Berry, Leonard L. (1983), "Relationship Marketing" in Emerging Perspectives on Services Marketing, L. Berry, G. L. Shostack, and G. D. Upah, eds. Chicago: American Marketing Association, 25-28.

(1995), "Relationship Marketing of Service-Growing Interest, Emerging Perspectives," Journal of the Academy of Marketing Science, 23 (4), 236-45.

Birmingham, Robert L. (1970), "Breach of Contract Damage Measures and Economic Efficiency," Rutgers Law Review, 24 (2/3), 273-92.

Brancher, Robert (1969), "Freedom of Contract and the Second Restatement," Yale Law Journal, 78 (4), 598-616.

Brodley, Joseph F. (1987), "The Efficiency Goals of Antitrust: Efficiency, Consumer Welfare, and Technological Progress," New York University Law Review, 62 (November), 1020-53

Bucklin, Louis P. and Sanjit Sengupta (1993), "Organizing Successful Co-Marketing Alliances," Journal of Marketing, 57 (April), 32-46.

Calamari, John D. and Joseph M. Perillo (1987), Contracts. St. Paul, MN: West Publishing.

Carney, William J. (1993), "The ALI's Corporate Governance Project: The Death of Property Rights?" George Washington Law Review, 61 (April), 898-959.

Corbin, Arthur L. (1963), Corbin on Contracts. St. Paul, MN: West Publishing Company.

Craswell, Richard (1988), "Contract Remedies, Renegotiation, and the Theory of Efficient Breach," Southern California Law Review, 61 (March), 629-68.

Cravens, David W. (1995), "Introduction to the Special Issue," Journal of the Academy of Marketing Science, 23 (4), 235.

Cribbet, John E. (1978), "Property in the Twenty-First Century," Ohio State Law Journal, 39 (1), 671-78.

(1986), "Concepts in Transition: The Search for a New Definition of Property," University of Illinois Law Review, I (4), $1-42$.

Crosby, Lawrence A., Ken R. Evans, and Deborah Cowles (1990), "Relationship Quality in Service Selling: An Interpersonal Influence Perspective," Working Paper No. 5, First Interstate Center for Services Marketing, Arizona State University. 
and Nancy Stephens (1987), "Effects of Relationship Marketing on Satisfaction, Retention, and Prices in the Life Insurance Industry," Journal of Marketing Research, 24, (November), 404-11.

Czepiel, John A. (1990), "Managing Relationships With Customers: A Differentiation Philosophy of Marketing," in Service Management Effectiveness, David E. Bowen, Richard B. Chase, Thomas G. Cummings, eds. San Francisco, CA: Jossey-Bass Publishers, 213-33.

Davidson, Joseph (1993), "Rules Allowing Manufacturers to Fix Prices With Distributors Are Rescinded," Wall Street Journal, (August II), B1.

Day, George S. (1990), Market Driven Strategy-Process for Creating Value. New York: The Free Press.

Dukeminier, Jesse and Jame E. Krier (1988), Property. Boston: Little, Brown and Company.

Dwyer, Robert F., Paul H. Schurr, and Sejo Oh (1987), "Developing Buyer-Seller Relationships," Journal of Marketing, 51 (April), 11-27.

Ellram, Lisa M. (1991), "A Managerial Guideline for the Development and Implementation of Purchasing Partnerships," International Journal of Purchasing and Materials Management, 27 (Summer), 2-8.

Epstein, Richard A. (1980), "The Static Conception of the Common Law," Journal of Legal Studies, 4 (2), 253-75.

(1985), "Why Restrain Alienation?" Columbia Law Review, 85 (5), 970-90.

Farnsworth, E. Allen (1987), "Precontractual Liability and Preliminary Agreements: Fair Dealing and Failed Negotiations," Columbia Law Review, 87 (2), 217-94.

(1990), Farnsworth on Contracts. Boston: Little, Brown and Company.

Ford, David (1980), "The Development of Buyer-Seller Relationships in Industrial Markets," European Journal of Marketing, 19 (5/6), 339-53.

Frankel, Tamar (1993), "The Legal Infrastructure of Markets: The Role of Contract and Property Law," Boston University Law Review, 73 (3), 389-405.

Frazier, Gary L., Robert E. Spekman, and Charles R. O'Neal (1988), "Just-In-Time Exchange Relationships in Industrial Markets," Journal of Marketing, 52 (October), 52-67.

Ganesan, Shankar (1994), "Determinants of Long-Term Orientation in Buyer-Seller Relationships," Journal of Marketing, 58 (April), 1-19.

Gensler, Howard (1985), "Property Law as an Optimal Economic Foundation," Washburn Law Journal, 35 (1), 50-78.

Gilmore, Grant (1974), The Death of Contract. Columbus, $\mathrm{OH}$ : Ohio State University Press.

Goetz, Charles J. and Robert E. Scott (1981), "Principles of Relational Contracts," Virginia Law Review, 67 (6), 1089-150.

Goldberg, Victor (1979), "The Law and Economics of Vertical Restrictions: A Relational Perspective," Texas Law Review, 58 (1), 19-129.

Graham, Daniel A. and Ellen R. Peirce (1989), "Contract Modification: An Economic Analysis of the Hold-Up Game," Law and Contemporary Problems, 52 (1), 9-32.

Gronroos, Christian (1990), "Relationship Approach to Marketing in Service Contexts: The Marketing and Organizational Behavior Interface," Journal of Business Research, 20 (1), 3-11.
Gundlach, Gregory T. (1994), "Exchange Governance: The Role of Legal and Nonlegal Approaches Across the Exchange Process," Journal of Public Policy \& Marketing, 13 (November), 246-58.

$\longrightarrow$, Ravi S. Achrol, and John T. Mentzer (1995), "The Structure of Commitment," Journal of Marketing, 59 (1), 78-92.

_ and Jakki J. Mohr (1992), "Collaborative Relationships: Legal Limits and Antitrust Considerations," Journal of Public Policy \& Marketing, 11 (November), 101-14.

Hartford-Empire Company v. United States (1945), 323 U.S. 370.

Hayes, Robert and Steven Wheelwright (1984), Regaining Our Competitive Edge. New York: John Wiley \& Sons.

Heide, Jan B. (1994), "Inter-Organizational Governance in Marketing Channels," Journal of Marketing, 58 (January), 71-85.

and George John (1988), "The Role of Dependence Balancing in Safeguarding Transaction-Specific Assets in Conventional Channels," Journal of Marketing, 52 (January), 20-35.

and (1990), "Alliances in Industrial Purchasing: The Determinants of Joint Action in Buyer-Supplier Relationships," Journal of Marketing Research, 27 (February), 24-36.

_ and (1992), "Do Norms Really Matter?" Journal of Marketing, 56 (2), 32-44.

Helper, Susan (1991), "How Much Has Really Changed Between U.S. Automakers and Their Suppliers?" Sloan Management Review, 32 (Summer), 15-28.

Holderness, Clifford G. (1985), "A Legal Foundation For Exchange," Journal of Legal Studies, 14 (June), 321-44.

Houston, Franklin and Jule B. Gassenheimer (1987), "Marketing and Exchange," Journal of Marketing, 41 (October), 3-18.

Hunt, Shelby D. (1983), "General Theories and the Fundamental Explanda of Marketing," Journal of Marketing, 47 (Fall), 9-17.

Iacobucci, Dawn (1996), Networks in Marketing. Los Angeles, CA: Sage Publications.

Jackson, Barbara B. (1985), Winning and Keeping Industrial Customers: The Dynamics of Customer Relationships. Lexington: D. C. Heath and Company.

Johnson, D. Bruce (1986), "Wealth is Value," Journal of Legal Studies, 15 (2), 263-88.

Kalwani, Manohar V. and Narakesari Narayandas (1995), "LongTerm Manufacturer-Supplier Relationships: Do They Pay Off for Supplier Firms?" Journal of Marketing, 59 (January), 1-16.

Kessler, Friedrich (1943), "Contracts of Adhesion-Some Thoughts About Freedom of Contract," Columbia Law Review, $43(1), 629-42$.

Kotler, Philip (1972), "A General Concept of Marketing," Journal of Marketing, 36 (April), 48-54.

(1990), Presentation at the Trustees Meeting of the Marketing Science Institute in November 1990, Boston.

and Gary Armstrong (1991), Principles of Marketing, 5th ed. Englewood Cliffs, NJ: Prentice-Hall.

Lovelock, Christopher H. (1983), "Classifying Services to Gain Strategic Marketing Insights," Journal of Marketing, 47 (Summer), 9-20.

Lyons, Thomas F., A. Richard Krachenberg, and Jon W. Henke, Jr. (1990), "Mixed Motive Marriages: What's Next for Buyer-Supplier Relations?" Sloan Management Review, 31 (Spring), 29-36.

Macneil, Ian R. (1974), "The Many Futures of Contracts," South- " ern California Law Review, 47 (3), 691-816. 
(1978), "Contracts; Adjustment of Long-Term Economic Relations Under Classical, Neoclassical, and Relational Contract Law," Northwestern Law Review, 72 (6), 854-905.

(1980), The New Social Contract: An Inquiry Into Modern Contractual Relations. New Haven, CT: Yale University Press.

(1981), "Economic Analysis of Contractual Relations: Its Shortfalls and the Need for a Rich Classificatory Apparatus," Northwestern University Law Review, 75 (6), 1018-63.

Meinhard v. Salmon (1928), 249 N.Y. 458.

Metzger, Michael B. and Michael J. Phillips (1983), "The Emergence of Promissory Estoppel as an Independent Theory of Recovery," Rutgers Law Review, 35 (3), 472-557.

Miles, Raymond E. and Charles C. Snow (1992), "Causes of Failure in Network Organizations," California Management Review, 34 (Summer), 53-72.

Mohr, Jakki J., Robert J. Fisher, and John R. Nevin (1994), "The Role of Communication Strategy in Channel Member Performance: Is More Collaborative Communication Better?" Working Paper No. 94-1 19, Marketing Science Institute, Cambridge, MA.

Narasimhan, Subha (1987), "Modification: The Self-Help Specific Performance Remedy," Yale Law Journal, 97 (1), 61-95.

Nicholson, Walter (1985), Microeconomic Theory: Basic Principles and Extensions, 3d ed. Chicago: Dryden Press.

Noordewier, Thomas G., George John, and John R. Nevin (1990), "Performance Outcomes of Purchasing Arrangements in Industrial Buyer-Vendor Relationships," Journal of Marketing, 54 (4), 80-93.

O'Neal, Charles R. (1989), "JIT Procurement and Relationship Marketing," Industrial Marketing Management, 18 (1), 55-63.

Parvatiyar, Atul, Jagdish N. Sheth, and F. Brown Whittington, Jr. (1992), "Paradigm Shift in Interfirm Marketing Relationships: Emerging Research Issues," working paper, College of Business Administration, Emory University.

Peterson, Robert A. (1995), "Relationship Marketing and the Consumer," Journal of the Academy of Marketing Science, 23 (4), 278-81.

Pollock, Frederick and Frederick Maitland (1898), The History of English Law Before the Time of Edward I, 2d ed. Cambridge: University Press.

Posner, Richard A. (1992), Economic Analysis of Law. Boston: Little, Brown and Company.

Reich, Charles A. (1964), "The New Property," Yale Law Journal, 73 (April), 733-87.

Restatement of Contracts (1981), St. Paul, MN: American Law Institute.

Robinson, Glen O. (1991), "Explaining Contingent Rights: The Puzzle of 'Obsolete' Covenants," Columbia Law Review, 91 (3), 546-80.

Rose, Carol M. (1988), "Crystals and Mud in Property Law," Stanford Law Review, 40, (February), 577-610.

Rose-Ackerman, Susan (1985), "Inalienability and the Theory of Property Rights," Columbia Law Review, 85 (5), 931-69.

Rosenfeld, Michel (1985), "Contract and Justice: The Relation Between Classical Contract Law and Social Contract Theory," lowa Law Review, 70 (4), 769-900.
Sakai, Kuniyasu (1990), "The Feudal World of Japanese Manufacturing," Harvard Business Review, 68 (November/December), 38-50.

Salmond, Deborah and Robert Spekman (1992), "A Working Consensus to Collaborate: A Field Study of Manufacturer-Supplier Dyads," Report 92-134, Marketing Science Institute, Cambridge, MA.

Scherer, Frederick M. (1980), Industrial Market Structure and Economic Performance. Boston: Houghton-Mifflin Company.

Scott, Robert (1990), "A Relational Theory of Default Rules for Commercial Contracts," Journal of Legal Studies, 19 (2), 597-616.

Shavell, Steven (1980), "Damage Measures for Breach of Contract," Bell Journal of Economics, 11 (2), 466-90.

Sheth, Jagdish N. and Atul Parvatiyar (1995), "Relationship Marketing in Consumer Markets: Antecedents and Consequences," Journal of the Academy of Marketing Science, 23 (4), 255-71.

Sinha, Deepak K. and Michael A. Cusumano (1991), "Complementary Resources and Cooperative Research: A Model of Research Joint Ventures Among Competitors," Management Science, 37 (9), 1091-106.

Smith, Adam [1776] (1976), An Inquiry Into the Nature and Causes of the Wealth of Nations, R. H. Campbell, A. Skinner, and W. Todd, eds. Oxford: Oxfordd University Press.

Spekman, Robert and Wesley Johnston (1986), "Relationship Management: Managing the Selling and Buying Interface," Journal of Business Research, 14 (December), 519-33.

Sterk, Stewart E. (1993), "Restraints on Alienation of Human Capital," Virginia Law Review, 79 (2), 383-460.

Trevelen, Mark (1987), "Single Sourcing: A Management Tool for the Quality Supplier," Journal of Purchasing and Materials Management, 23 (Spring), 19-24.

Uniform Commercial Code (1978), American Law Institute and the National Conference of Commissioners on Uniform State Laws, 4th ed. St. Paul, MN: West Publishing Company.

Varadarajan, P. Rajan and Daniel Rajaratnam (1986), "Symbiotic Marketing Revisited," Journal of Marketing, 56 (October), 1-17.

Webster, Frederick E. (1992), "The Changing Role of Marketing in the Corporation," Journal of Marketing, 56 (4), 1-17.

Weitz, Barton and Sandy D. Jap (1995), "Relationship Marketing and Distribution Channels," Journal of the Academy of Marketing Science, 23 (4), 305-20.

- Stephen B. Castleberry, and John F. Tanner (1992), Selling-Building Partnerships. Boston: Richard D. Irwin.

Williamson, Oliver E. (1968), "Economics as an Antitrust Defense: The Welfare Tradeoffs," American Economic Review, 58 (2), 18-32.

(1979), "Transaction Cost Economics: The Governance of Contractual Relations," Journal of Law and Economics, 22 (2), 233-61.

(1985), The Economic Institution of Capitalism. New York: The Free Press.

Wilson, David T., Shirish P. Dant, and Sang-Lin Han (1990), "State-of-Practice in Industrial Buyer-Supplier Relationships," Report 6-1990, Institute for the Study of Business Markets, University Park, PA. 
Copyright of Journal of Public Policy \& Marketing is the property of American Marketing Association and its content may not be copied or emailed to multiple sites or posted to a listserv without the copyright holder's express written permission. However, users may print, download, or email articles for individual use. 